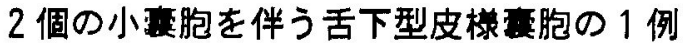

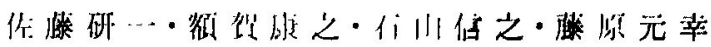

\section{A case of dermoid cyst with two daughter cysts}

Kenichi SATo - Yasuyuki Nukaga - Nobuyuki IshiYama - Moloyuki fujiwara

緒

言

口腔底に出現する萣胞には，胎生残遗組㵶に由来する

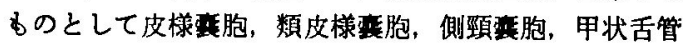

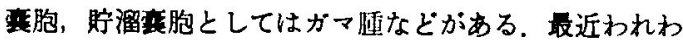
れは, 舌下部の皮様霞胞に 2 個の小共胞が随伴し, 計 3

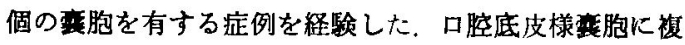
数の小塞胞が発現する例はきわめてまれであり，本邦文 献では過去に 4 例をみるのみであった，組織学的にも興 味深いものがありここに詳細を報告する。

\section{症例}

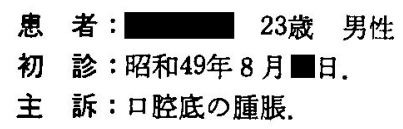

現病歴 : 初診約 2 週間前に, 勤務先の口腔 検 診によ り，口底部の連脹を指摘されたがそそれまで特に違和感 はなかった。

現 症 : 体格栄盖中等度, 健康な男子で, 臨床諸挨査 飞も異常所見はみられなかった。顔貌は左右对称性て， オトガイ下部にも特に腫脹は認めなかった（写直 1). 開口障害むなく，口腔内をみると舌後退時に，舌下部中 央に境界明睹なっルミ大の腫脹が出現する，表在粘膜に 特に炎症所見は認められず，粘膜下には抵抗軟弱な盾瘤 をふれた。 オトガイ下部を圧迫すると，舌下部に膨隆を 增すが，王痛も自発痛す認めなかった（写真 2).

臨床診断：舌下部皮様軗胞。

処置および経過：手術は両側下額孔伝達麻醉および局 所浸潤麻醉を用い，ロルトン氏管の損笏をさけて，舌下

干集大学医学部迷科口腔外科学教室 (主任: 堀越達 郎教授)

Department of Oral Surgery, School of Medicine, Chiba University (Chief: Prof. Tatsuro Horikoshi) 受付日：昭和53年 9 月 18 日

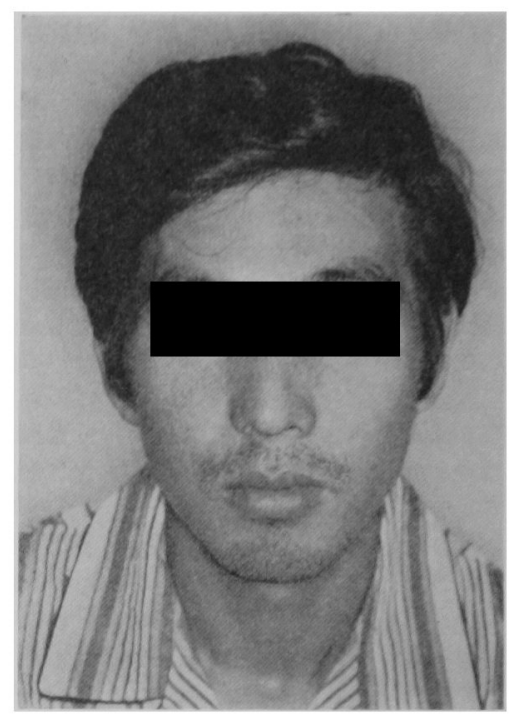

写恧 1 患者䫆貌

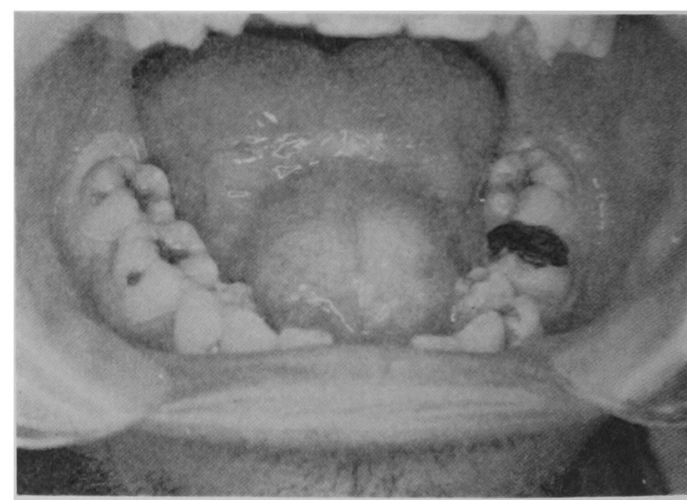

写重 2 口腔内所見

部正中に約 $3 \mathrm{~cm}$ の緹切開を施し，粘膜下に犋胞壁を露

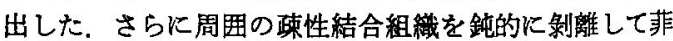
薄な亯胞壁を全面的に露出した，その際，主蕉胞の底部 とわずかに線維性に連続している2 個の小䒼胞がオトガ イ舌骨筋の中間に互に独立して存在するのを認め,これ 


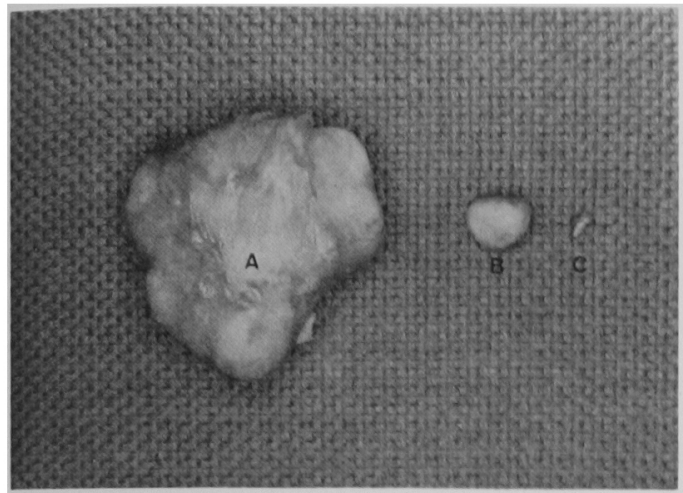

军竞 3 摘出物肉眼所見

A：主重胞，B，C：小暴胞

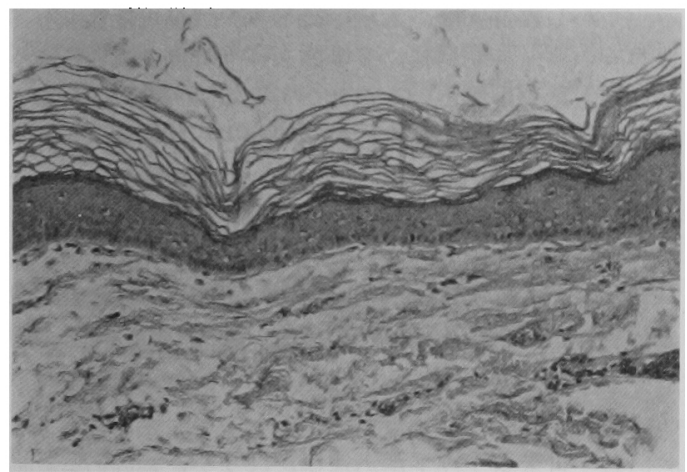

写真 4 摘出物病理組截学的所見

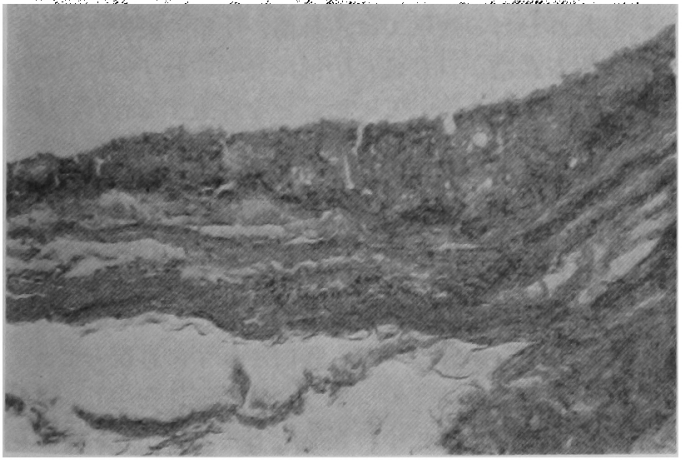

写真 5 路子状の数層の上皮被覆. 線毛は認められ ない。

らも同時に摘出した.

手術創は 1 次的に链合閉鎖した，経過は良好で，患者 は1週間後に退院した。

摘出物の肉眼的所見：主栾胞はほぽクルミ大で軟弱な 抵抗を示し，その壁は菲薄である。

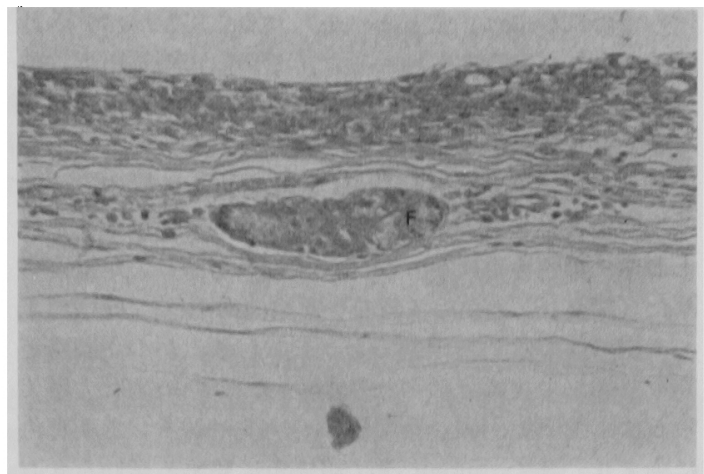

军卉 6 篗胞内の皮脂腺（下）

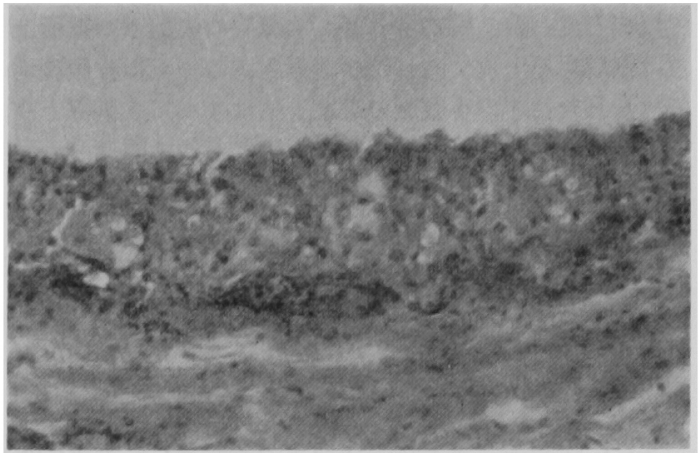

写真 7 小玫胞の被覆上皮

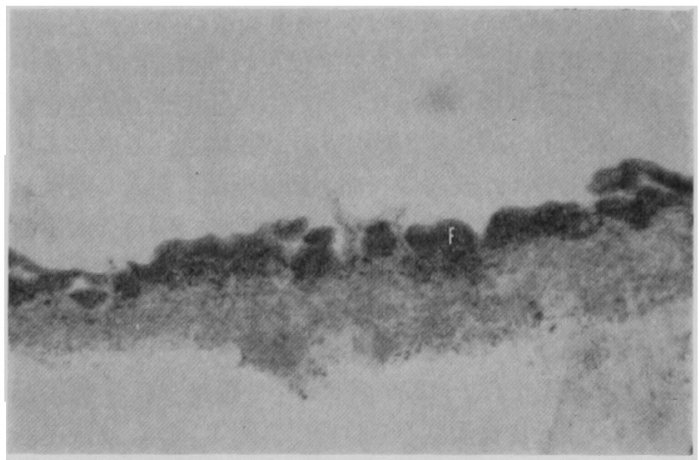

写卉 8 小苗胞にみられた脂肪染色陽性の被覆上皮

内谷物は，淡黄色でチーズ様の均一な性状を示してい た. 2 個の小栾胞はそれぞれ直径 $10 \mathrm{~mm}$ と $3 \mathrm{~mm}$ の球 状の腫瘤で，外見は主洼胸とほぼ同様であった（写高 3).

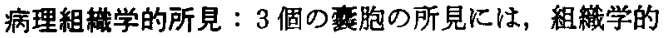
に多少の差異が認められた，主䔄胞の所見は，䧶胞壁の 大部分の内面が角化扁平上皮でおおおれ，基底細胞層上 り角化に至る段階が明瞭に 認められた（写卉 4). 雚胞 


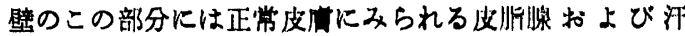
腺，毛軍などは存在しなかった，しかしこの有爽上皮は 一部で激次菲薄となり，ついにそれが消失する部分がみ

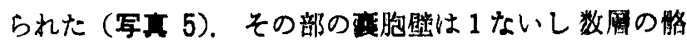

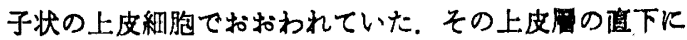
は皮脂腺之思われる組織があり，茬胞然を被覆する上皮 と形体，染色性等に上り踏接な俰があることが推定さ

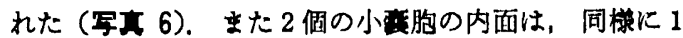

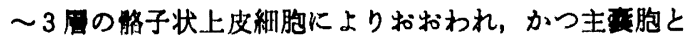
異なり扁平上皮は想められなかった。この緗胞は大型で 数石状に配列し，かつ原型贵はーマトキシリンで淡青色

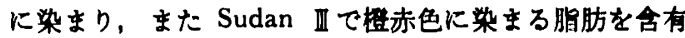

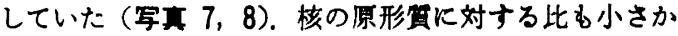
った．これらの所見は，正常皮席にみる皮脂腺にきわめ

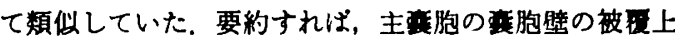
皮は重層扁平上皮であったか，烡胞壁の一部に皮脂腺が 認められたこと，小垂胞の被嗄上皮はすべて皮脂腺上皮 であったことから，これらの3塞胞は共通に咸連する母 地から発生した皮様童胞であると診断された。

考

按

New \& Erich"27)の多数の統計によれば，人体にみる 皮様烡胞は肛門後部 $44 \%$ ，卵巣 $42 \%$ ，頭頸部 $7 \%$ どが みられ，頭頸部の発現頻度はあまり多くない：また頭頸 部 103 例の 5ち口腔底のむのは23\%で，眼䆚領域の50\% の次に多くみられた，New \& Erich は，皮棣弯胞を次 の 3 型に 分類している。１）奇型腫型の 先天性皮様紊 胞（複合構造をとり，胎生胚芽上皮の分割細胞の一部か; 迷入し，休止状態にあったか，のちに活性化し望胞を形 成したもの），2）後天的嵌入性皮様毫胞（外侮により 発生するすので，皮席の一部が創偤深部に嵌入し增殖し たものであり，壁は扁平上皮よりなる)，3）先天性埋 没性皮様紊胞（胎生原基の痽合線に沿って，上皮細胞の 迷入することにより発生する)， 口腔底に 発生するるの は3）に属するすのが多いとされている.

本症に関しては，1859年 Rosar ${ }^{28)}$ 以来多数の 報告が ある，口腔底皮様费胞の発生機序に関しても諸説があ り，Kaufman (1884) 24) の皮店小片迷入説，Bergmann $(1913)^{20)}$ の胎生期外胚葉の迷入するとい5鰓弓説, Hassel (1913 ${ }^{23)}$ の 頸洞の残遗物によるとする頸洞説, Colp (1925) 21)の鰓弓ならびに 無対結節異常埋没説など

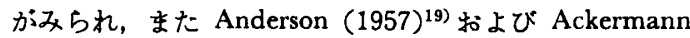
$(1953)^{18)}$ は，一般に先天的な原因によるが外傷または炎 症に由来することもあるとしている，さらに Meyer $(1955)^{26)}$ は, 口腔底の異個体発生的衰胞を一括して, 次 のごとく分類した。

1）表皮様毫胞：皮庙附属器官をるたない表皮性衰 胞.

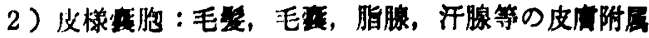
器官を有する表皮性晎胞。

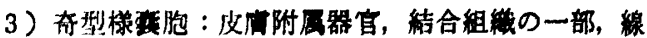
維，骨，解，血管，呼吸器あるい江消化器系組織等を有 する算胞。

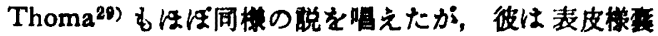
胞に一部皮河附属器官を有するるのを加えている。本邦

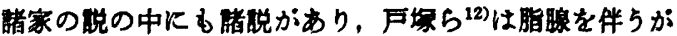

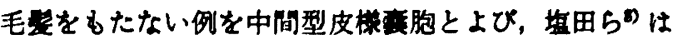

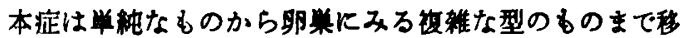

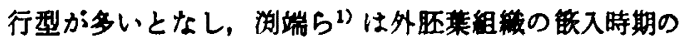
暒速により，いろいろな型を生じ，1つでる皮庙附属器官 を有すれば皮粎算胞と解すべきであるとし，国見りはこ

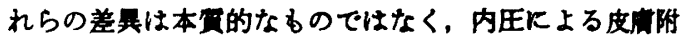
属器官の菱粨消失に上るるのと解すべきであるとしてい

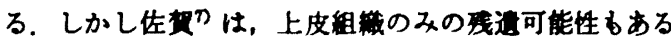

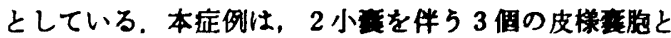
みられ，珍しい例といらことがでさる。このような皮 様变胞の多発例は額骨内に数例の報告6) がみられるか， 口腔底には山(県 ${ }^{16)}$ ，古本 ${ }^{2)}$ ，山下 ${ }^{15)}$ ，上田 ${ }^{13)} 594$ 報告 をみるのみである．古本らの 2 個の皮様墓胞恃皮下結合 組䄉相当部に皮脂腺のみがみられ，大暻胞俚正中矢状面 にありオトガイ舌骨筇の上下にまたがり，長径 $51 \mathrm{~mm}$ を示した，その小萁胞は $14 \mathrm{~mm}$ の長径を有し，正中部 でオトガイ骨下䋧に近く存在した。両者の間陸は約 3 cm であり，全く独立性に発育したるのであろらとされ ている. 古本および上田の症例にはすでに初回の手術既 往（それぞれ8か月および10年の間隔）があり，手術の 外偒による皮问組繖の迷入も一応，考えられないことは ない，われわれの症例では，外侮，手術の経検は全くな く，3個の授胞が口腔底正中部にあり，わずかに小量の 結合組織により車絡していたことを考成すると，これら は同一の機序により発生し，胎生期に複数の原基が迷入 したことが考えられる。.すなわち，われわれの例は， New \& Erich の第 3 類に近いるのと考えられる. 胎生 時複数の原基が迷入した場合，あるるのは個体の発育と ともに吸収され臨床的には 1 個の衰胞として出現するこ とああろう。しかしいずれる吸収されす゚に存続したとす れば，局所環境の条件等により発育に遅速を生し，ある ときは本例のよ5に大小の韭胞として見い出され，ある ときは上田らのことと相当期間を経て 2 個目の烡胞が見 い出されることもあろら。この点より，処固時に性手術 野の十分な点検が望まれる。

McClintock は，甲状舌管宾胞と皮様莫胞とは特定の 部位において鑑別が困難な場合があるといった，この点 について石川らの著書をみると，甲状舌管震胞との躍別 に注意を要する例は，舌下部またはオトガイ下部湀生 した皮様衰胞の 4 ないし10\%にみられるようである. 本 症例を外科解剖学的および病理組織学的に検討すると， 
次のよ5な事がいえる。一般に甲状舌管蓄胞は场越らの

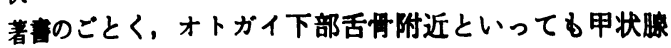
と舌盲孔の間に発生するるのであり，外科的にはオト

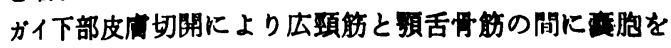
見い出し，索状物か辞骨を贯通し，あるいはその㚲上直 下を通過して，オトガイ舌骨筋の間を舌亩孔の方向に発 育するるのである。したがって手術の要点は，辞の一 部切除と䫑舌骨筇正中切的に上り舌下部に到连し，オト ガイ舌骨筋の間を舌目孔に向けて制離を進め，それによ り雚胞扰よび索状物を完全切除ナることにある．本例の

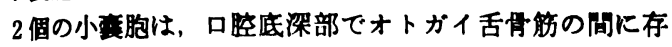
在していた，局所は舌骨に近接する部位で，甲状舌管落 胞の多くみられる部位である．しかし主变胞は口底部粘

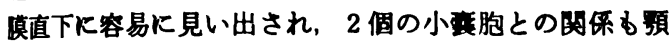
舌骨筋を貫通するすのではなく，舌亩孔には遠いすので あった。 したかっって外科的解剖学的には，甲状舌管算胞 の可能性はきわめて少ないるのといえる，また組樴学的

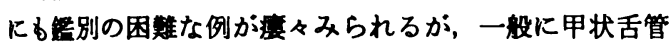

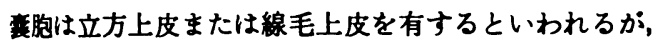
必ずしすすべてがかかる粠造を示するのではない，田縁 $ら^{100}$ の報告例のよらに一部が重層扁平上皮化した線毛上

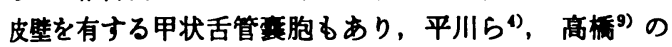
ごとくガマ畽の中にす線毛を認めたといら例がある. 本 例は，主烡胞が多層の扁平上皮により被覆されていたこ と，その一部ならびに小震胞にす皮脂腺が存在していた こと，また甲状腺組織中線毛上皮が認められないことか ら，皮様菨胞と診断した。

家鬼の頻下部に皮庙弁を移植した露埼 ${ }^{11)}$ の実検的研究 では，皮様萲胞か発育腫大する場合に，扁平上皮下に存 在する皮脂腺は渐次上皮と互に接するよらになり，のち に上皮か脱落して烡胞腔に皮脂腺が開腔する．しかし皮 脂腺上皮による被覆は永続せず，扁平上皮は皮脂腺の底 部に伸展增殖し，最終的には皮脂腺は排除されて，莫胞 壁は扁平上皮化して釉わるといわれている。 また感染等 の合瓶により，この過程にも多少の変化がみられる．臨

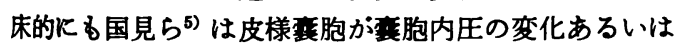
感染の合併等により，その所見に影霎を受けることをあ

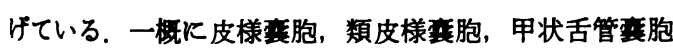
といっても，その発生母胎, 経過, 局所の環境等によ ク，上述のごとく蓄胞の組織学的所見にるかなりの偏差 がられるので, 摘出物は可及的連続切片により検討す ることが大切である.

皮様表胞は，男性より女性にわずかに多く，年龄的に は16〜35䠞に多いようである.

Meyer ${ }^{26)}$ は，これを皮庙附属器官の活動が最も活発な 生理学的な条件と結びつけている．その意味では，本症 例る23歳の男子とい5生理的活性の最む高い年代のるの であった。 また皮表烡胞は口底部における発現部位によ ク，多くの学者 ${ }^{3,20,22)}$ はこれを舌下型, オトガイ下型,
「イカガイド型に分頪して特り，そしてまた舌下型か552 〜71\%と而い顷度を小している16,17)。しかしまれには，

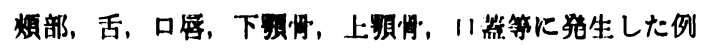

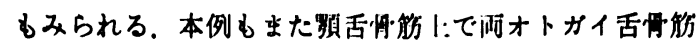

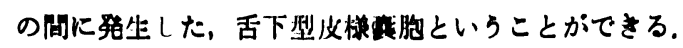

\section{結嘼}

23藏男子の舌下部正中にみられたクルミ大の|: 萁胞 と，その底部のオトガイ舌骬筋间に存在した 2 個の小 胞よりなる，口底部皮棣咅胞の1 例を報告した。このよ らに数個の小䔶胞を随伴する例はきわめてまれらしく， また变胞暨の一部に皮脂腺の上皮の被嗄がみられたこと む特異的であった。

\section{引用文 献}

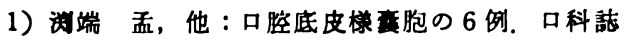
13: 491964.

2) 古本克唐, 他: 頋部及び舌下頋下部に 2 コの皮

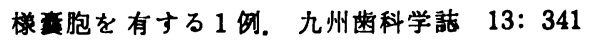
1959.

3）荻崎爲行：巨大なる口腔底皮様要胞の 1 例. 耳 咽喉科 2: 5626551929.

4）平川正輝，他：萁胞内に崸毛を有するガマ連の 例. 㧘科学雅誌 8: 1031951.

5）国見正明：口腔底皮㥞衰胞 2 例。耳咽喉科 27: 3911955.

6）成田令博, 他：䫓骨内に 発生した Epidermoid cyst の 2 侧. 口科誌 11: 1871962.

7)佐賀宗行: 口腔底皮㥞衰胞の一例. 山口医学 9: 16131960 .

8）塩田重利, 他：口腔底皮様喜胞の一例。品病誌 24: 3851957.

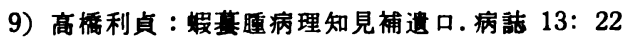
1939.

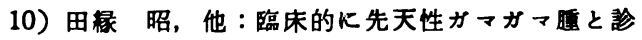
断された甲状舌管违残性重胞の 1 例。只外誌 18: 3661972.

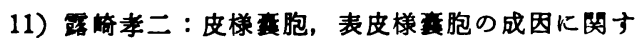
万知見補遗. 口外誌 22: 4521976.

12）戸塚善之助, 他：口腔底皮様㟟胞の 6 例に関す

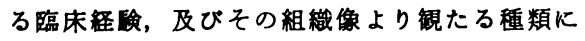
ついて。目本米科医学会会誌 37: 1501939.

13）上田忠, 他: 興味ある皮様晎胞の 1 例. 口外 誌 20: 7671974 .

14）山県 晋, 他 : 二個独立して発見したる舌下部 皮様言胞の一症例。古本上り引用。

15）山下佐英, 他：皮様真胞の 11 例. 口外誌 19: 4801973.

16）河合 幹, 他: 口腔底皮样莀胞の 1 例ならびに 文献的考察. 口外誌 11:244 1965.

17）平野一弥, 他: 皮样亯胞の 1 例. 菌科月報 29: 
1651955.

18) Ackermann, L.V.: Surgical Pathology. Mosby Co, St Louis, 1957, p 1185.

19) Anderson, W.A.D.: Pathology. ed 3, Mosby Co, St Louis, 1957.

20) Bergmann, E.: Handbuch der prakt Chir. Colp 上り引用.

21) Colp, R.: Dermoidcysts of the floor of the mouth. Surg Gynec \& Obst 40: 1831925.

22) Debonnele: Meyer, I.上り引用。

23) Hassel, R.: Die Mundbodendermoide. Beiträge kl Chir 83: 3321913.

24) Kaufman: 荻崎, Colp 上り引用.

25) McClintock, J.C.: Lesions of the thyroglossal tract. Arch Surg 33: 8901936.

26) Meyer, I.: Dermoid cysts (Dermoids) of the mouth. OS OM OP 8: 11491955.
27) New, G.B., Erich, J.B.: Dermoid cysts of the head and neck. Surg Gyne \& Obst 65 : 481937.

28) Rosar: Colp 上り引用.

29) Thoma, K.H.: Oral Pathology, ed 5, Morby Co, St Louis, 1960.

30) Ward, G.E., Hendrick, J.W., Chambers, R.G.: Thyroglossal tract abnormalitiescysts and fistulas. Surg Gynec \& Obst 89: 7271949.

31) Montgomery, H.: Dermatopathology. Harper \& Row, New York, Evanston and London, 1967.

32) Knapp, M.J.: Lingual sebaceous glands and a possible thyroglossal duct. Oral Surg 31: 701971. 